Maurer School of Law: Indiana University

Digital Repository @ Maurer Law

\title{
What Constitution Does Europe Need? The House that Giscard Built: Constitutional Rooms with a View
}

Paul Craig

Indiana University Maurer School of Law, pcraig@indiana.edu

Follow this and additional works at: https://www.repository.law.indiana.edu/facpub

Part of the Constitutional Law Commons, and the European Law Commons

\section{Recommended Citation}

Craig, Paul, "What Constitution Does Europe Need? The House that Giscard Built: Constitutional Rooms with a View" (2003). Articles by Maurer Faculty. 2453.

https://www.repository.law.indiana.edu/facpub/2453

This Article is brought to you for free and open access by the Faculty Scholarship at Digital Repository @ Maurer Law. It has been accepted for inclusion in Articles by Maurer Faculty by an authorized administrator of Digital Repository @ Maurer Law. For more information, please contact rvaughan@indiana.edu. 


\title{
THE FEDERAL TRUST \\ for education \& research
}

ONLINE PAPER 26/03

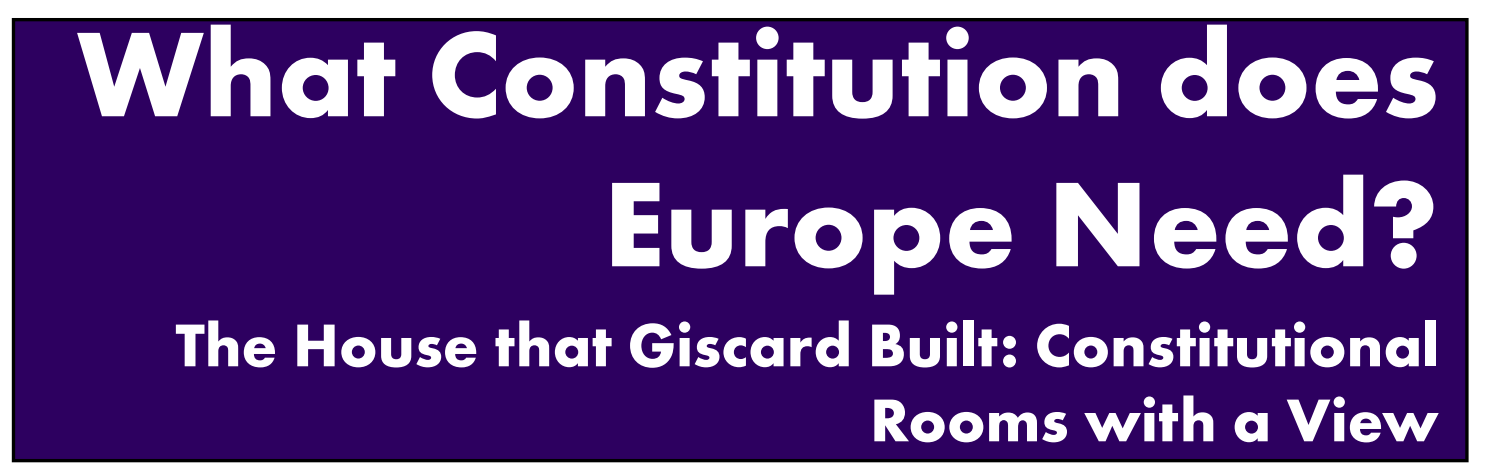

\author{
Paul Craig \\ University of Oxford
}

paul.craig@law.oxford.ac.uk

August 2003 
(C) Paul Craig, 2003

Published in Great Britain by The Federal Trust for Education and Research, 7 Graphite Square, Vauxhall Walk, London SE11 5EE Tel. +44 (0) 2077354000 http://www.fedtrust.co.uk/eu_constitution

The Federal Trust for Education and Research is an independent think tank which aims to enlighten public debate on issues arising from the interaction of national, European and global levels of government.

Charity (Registration No. 272241) 


\section{What Constitution does Europe Need?} The House that Giscard Built: Constitutional Rooms with a View

\section{Paul Craig*}

Any evaluation of the draft EU Constitution will be contentious. Commentators will disagree as to general matters of constitutional design, as to what are to be regarded as the 'central' features of the Constitution, and they will disagree also as to whether the $\ddot{A}^{\prime}$ answers' provided in the Constitution to any of the key issues is satisfactory.

Let me state at the outset that I believe that judged in terms of constitutional design the draft Constitution is a success. The decision to have one document, divided into four parts, the first of which incorporates the constitutional principles ${ }^{1}$ that are to govern the Union, is to be preferred to other suggestions for distinct Treaties, or a Basic Treaty plus an ancillary Treaty. The Giscardian choice has a Gallic elegance, and is more accessible than any of the rival constitutional designs.

Any choice of the central features of the Constitution will, as stated, be contentious. I believe however that the topics discussed in this one hour lecture would appear on most such lists. The analysis which follows evaluates the draft Constitution from both a horizontal and a vertical perspective. The horizontal perspective looks at the key features in the draft Constitution that affect the way in which the Union institutions operate. There will be an analysis of the inter-institutional balance of power between the European Council, the Council, the EP and the Commission. This will be followed by consideration of the Constitutional provisions concerned with the Charter of Rights and the Community Courts. The vertical perspective considers the provisions in the Constitution that affect the relationship between the Member States and the Union. The principal topics discussed are competence, the primacy of Union law and the Charter of Rights.

\section{The Horizontal Perspective: Power, Control and Accountability within the EU}

\section{(a) The Inter-Institutional Division of Power within the EU}

The inter-institutional balance of power within the EU is central to the new constitutional order. It is central when viewed from the perspective of legitimacy/democracy, and from the perspective of efficacy. It is not therefore surprising that this topic, which is dealt with in Title IV of Part 1 of the Constitution, has been so contentious. This is reflected in the fact that this 'room' was empty in the original preliminary draft Constitution published, and by the fact that discussion of the Union institutions took place in plenary sessions of the Convention, not in working groups as was the case with other topics. The contentious nature of this subject matter is further evidenced by the fact that the content of Title IV is still subject to detailed debate, and amendments are being considered to a greater extent than with other parts of the draft Constitution.

It is important when reading the proposals to be aware of certain fundamentals as to how the Union has operated thus far. Inter-institutional balance, as opposed to separation of powers, has characterised the relationship de jure and de facto between the major players: the European Council, the Council, the European Parliament and the Commission. The importance of this balance has been stressed yet again in the documentation to emerge from the Convention concerning Title IV. ${ }^{2}$

\section{Legislative Power}

This institutional balance is most readily apparent in relation to the legislative process. The Commission has the right of legislative initiative. The EP and the Council both partake in the consideration of legislation and do so now on an increasingly equal footing under the co-decision procedure of Article 251. The draft Constitution has maintained the essentials of the institutional balance that has characterised the legislative process. The Commission has retained in general terms its gold standard, the right of legislative initiative, Article I-25(2). The EP and the Council are said to jointly enact legislation, Articles I-19(1) and I-22(1). The co-decision procedure under which such legislation is jointly enacted is now deemed to be the ordinary legislative procedure for the making of European laws and framework laws, Article l-33(1). The reach of the co-decision procedure has been extended to cover more areas than hitherto. This treatment of legislative power in the new draft Constitution is to be welcomed. It is generally accepted that the co-decision procedure has worked well. It allows input from the EP, representing directly the electorate, and from the Council, representing state interests. Article 251 (now to be III-298) provides a framework for a deliberative dialogue on the content of the legislation between the EP, Council and Commission. The extension of co-decision to cover new areas is a natural development, building on what has occurred in earlier Treaty reform. It enhances the legitimacy of Union legislation and its democratic credentials by enabling the EP to have input into the making of legislation in these areas.

\section{Executive Power: The Election of the Commission President}

It should also be recognised that inter-institutional balance has shaped executive power within the Union. This power has not, in the past, resided in a single institution. It is exercised in part by the Commission, which exercises a plethora of executive type functions, including the administration of legislative programmes, the planning of the legislative agenda, the negotiation of Treaties with third parties, and the framing of the budget. It would however be quite mistaken to think of the Commission as the sole repository of executive power within the existing constitutional order. The Council and the European Council also wield executive power. The European Council in particular is especially important in this respect. The Treaties may say relatively little about the powers of the European Council. The reality is that nothing of major importance happens within the EU without its approval. It has a major say in setting the legislative agenda, in setting the Union's priorities, in deciding on the pace and direction of change within the Union, whether this be in relation to the timing of monetary union, or enlargement.

There have however been major debates within and outside the Convention concerning the location of executive power in the Union. There are three dimensions to this debate that must be disaggregated, even though they are linked: the election of 
the Commission President, the Presidency of the Union, and the creation of an EU foreign minister.

Let us turn first to the election of the Commission President. The Commission has in the past generally been opposed to the idea that its President should be elected. It feared the politicisation that might result. It has more recently changed its view, and come to accept that some form of elected President would enhance its legitimacy within the Union institutions, and that it would thereby strengthen the claims of the Commission President to be the President of the Union as a whole. The argument for electing the Commission President has also been supported on democratic grounds, since the voters would then be able, directly or indirectly, to 'throw out' incumbents of political office that they disliked. The debate then shifted as to who should elect the Commission President. Such an election could be direct, taking place at the same time as elections to the EP, with voters choosing the President by direct vote. The election could be indirect, the decision being taken by the EP. There were also considerable differences of view about the consequences of any such change. There are some who feel that direct or indirect election would not markedly affect the modus operandi of the Commission. It would be very much business as usual, except the Commission would have the added legitimacy that comes from the election of its President. There are others who accept that election would significantly alter the character of the Commission. They acknowledge that election would lead to politicisation, since a directly or indirectly elected President would necessarily have a political platform or agenda. They regard such a development with equanimity in the following sense. They argue that the legislative and executive powers of the Commission inevitably entail political choices, that they are not and cannot be politically neutral, any more than can the exercise of the analogous powers within domestic polities. Better then for this to be out in the open so that voters can directly or indirectly make their considered choices. The impact of electing the Commission President has however not been fully thought through even by those in this latter camp. It is questionable whether the Commission could continue to retain its near monopoly of legislative initiative in such circumstances. The EP has not surprisingly been in favour of an indirectly elected Commission President. These options were premised on the assumption that the Member States would be willing to accept a regime in which they surrendered control over the Presidency of the Commission to the EP.

The solution in the draft Constitution has brought a sharp dose of political reality to the debate. The Member States have, unsurprisingly, not been willing to surrender this power. The articles on the institutions make interest reading in this respect. Article I-19(1) states that the EP shall elect the President of the Commission. The retention of state power is however immediately apparent in Article 1-26(1). The European Council, taking account of the elections to the EP, puts forward to the EP the European Council's candidate for Presidency of the Commission. This candidate shall then be elected by the EP. If the candidate does not get the requisite majority support, then the European Council puts forward a new candidate.

The result, at least for the present, is that the Commission President is indirectly-indirectly elected. It is difficult to believe that this will do much to enhance the legitimacy of the
Commission, insofar as this is felt to be a desired or necessary objective. Nor will it enhance the democratic credentials of the Union, in the sense of allowing the voters to throw out those whom they dislike, and install another person with a different policy agenda. The Commission President is however given greater power over the choice of individual Commissioners than hitherto, Article I-26(2).

\section{Executive Power: The President(s) of the Union: A Milliner's Tale}

The other major debate about executive power has been concerned with the Presidency of the Union as a whole. This has at times bordered on the arcane, and much of the discussion smacks of a milliner's tale: the talk is of one hat, two hats, shared hats and the like. This should not mask the issues of real power that are at stake. Two main positions can be identified.

A prominent version of the single hat view was that there should be one President for the Union as a whole, that the office of President should be connected formally and substantively with the locus of executive power within the Union, and that the President of the Commission should hold this office and exercise this power. The Presidency of the European Council should continue to rotate much as it has done in the past, on a sixmonthly basis. The real 'head' of the Union would on this view be the President of the Commission, whose legitimacy, so it was hoped would be increased by the very fact that he or she had been elected.

A prominent version of the double hat view is that there should be a President of the Commission and a President of the European Council, that executive power would be exercised by both. It is central to this view that the Presidency of the European Council would be strengthened. It would no longer rotate between states on a six-monthly basis. It was felt that this would not work within an enlarged Union, and that greater continuity of policy would be required. This view was advocated by a number of the larger states, but was opposed by some of the smaller states, which felt that the Presidency of the European Council would be dominated by the larger Member States. The draft Constitution reflects the second view. Article I-21 stipulates that the European Council shall elect a President for two and half years, renewable. Thisn'choice' was pushed through by Giscard d'Estaing, and the degree to which it had support from other members of the Praesidium was debatable. (issue about name: chair or President).

Whether this 'conclusion' concerning executive power is what we should want from the new constitutional order can be assessed in terms of principle and practical politics.

In terms of principle, the contending arguments are as follows. Those who are against the second view argue that there should be one locus of executive power within the Union, by parity of reasoning with domestic polities. They argue further that the divide in executive power will lead to confusion of responsibility as between the President of the Commission and the President of the European Council, and that this is even more likely to occur because the nature of their respective executive responsibilities is not clearly defined. The argument the other way is however forceful. Executive power within the Union has always been divided de facto between the Commission and the 
European Council. This may not be neat, but it is how the Union has worked for the last thirty years at least. In terms of principle there is on this view nothing wrong with executive power being shared by a body representing state interests, and a body representing the Community interest. It is moreover clear that for the last decade at least the Commission and the European Council have worked symbiotically in developing the Union's agenda.

In terms of practical politics, how matters will work in practice, we can also perceive two views. There are some who accept the inevitability of the double Presidency, recognising that the larger Member States would not accept one President for the Union, this post being held by the Commission President. They take the view however that this does not matter too much, since the Commission President will, in practical terms, be the dominant partner, by force of his legal powers, and by force of having the Commission bureaucracy to support his initiatives. They point in support to the fact that while Giscard secured the extended Presidency of the European Council within the Constitution, other aspects of his proposals, for a vice President of the European Council, plus a bureaucracy in support, hit the cutting room floor. They imagine therefore a contest between a Commission President and the President of the European Council in which the latter does not have the institutional support to rival the former. I do not believe this picture of how the two Presidencies will interact. The European Council has not hitherto had an established institutional support mechanism to rival that of the Commission, but this has not prevented it from exercising real input into the pace and nature of the Union's development. It is moreover reasonably predictable that the strengthened President of the European Council will develop an institutional support mechanism, whether this is written into the Constitution or not. The recent proposals talk in terms of his drawing on the General Secretariat of the Council for support. It would nonetheless be surprising if this did not blossom into a species of institutional support suited to the specific needs of the-'new' European Council. The history of the Treaties thus far provides ample examples of institutions which have developed, often outside the strict letter of the Treaties, as a response to pressures or concerns relating to institutional balance of power within the Community as a whole. The European Council itself began life in this way, and COREPER and the Comitology committees are further examples of the same phenomenon.

\section{Executive Power: The Foreign Minister with the Shared Hat}

The third main issue concerning the locus and nature of executive power in the Union concerns the creation of the post of EU foreign minister. The post has been created by Article I-27: the Union's foreign minister is to conduct the Union's common foreign and security policy. The idea that executive power within the Union is divided between the European Council and the Commission is personified in this post. The foreign minister is to be appointed by the European Council by qualified majority, with the agreement of the Commission President. Once appointed the foreign minister operates as one of the Vice Presidents of the Commission.

\section{(c) The Charter of Rights}

There has, as is well known, been much debate as to the legal status of the Charter of Rights post the Treaty of Nice. The draft Constitution has made the Charter of Rights binding, Article I-7, and the entirety of the Charter forms Part II of the Constitution. This is to be welcomed. If we are to have a Constitution then it is right and proper for the Charter of Rights to form an integral part of the constitutional document. It should be binding and it should be clear that it is binding. The Constitution achieves these objectives. The way in which the Charter is brought into the Constitution is moreover imaginative and to be applauded. The binding nature of the Charter is made clear in Article I-7(1). It would however have unbalanced Part I to incorporate the Charter in its entirety into this part of the Constitution. It would also have been undesirable merely to append it as a Protocol. The solution of making the Charter Part II of the Constitution works well in terms of constitutional design, and the positioning of the Charter text reflects its importance. We should be equally mindful of the consequences of taking this step. There is no doubt that rights-based claims against the legality of Union and Member State action will increase, and that this will lead to the further juridification of political life within the Union. This is especially so given the broad list of rights protected by the Charter. The amendment to the Charter, whereby a distinction has been drawn between legally enforceable rights, and principles that should guide legislative and executive action, but not give rise to a direct cause of action per se, will have to be worked out by the Community courts over time. The ECJ and High Court will also have to address the complexities surrounding the relationship between the Charter rights and provisions of the Constitution. Article II-52(2) states that rights recognised by the Charter for which provision is made in other parts of the Constitution shall be exercised under the conditions and within the limits defined by these relevant Parts. The application of this provision will be problematic. This will be so even if Article II$52(2)$ is altered as is being suggested to read that rights recognised by the Charter that merely restate rights in other parts of the Constitution will be exercised under the same conditions and within the same limits.

The Constitution also stipulates that the Union shall seek accession to the ECHR, Article 1-7(2). This may be desirable, but the legal complexities should not be underestimated.

In procedural terms, applicants who seek to challenge Union acts on the basis that they infringed Charter rights that are also found in the ECHR will in most circumstances have to begin their actions in national courts, seek a preliminary reference to the ECJ, have their case heard by the ECJ, and then if they are dissatisfied with the outcome, pursue their claim before the ECHHR.

In substantive terms, Article II-52(3) provides that Charter rights that correspond to rights guaranteed by the ECHR shall be given the same scope and meaning as those in the ECHR. This is subject to the caveat that Union law can provide more extensive protection. ${ }^{3}$ This provision requires the identification of those rights which correspond to those guaranteed by the ECHR. The task is facilitated by guidance from the drafting process, and was addressed by an explanatory memorandum. ${ }^{4}$ The memorandum is not legally binding but it does constitute a useful guide. It concluded that the right to life, the prohibition of 
torture, the prohibition on slavery and forced labour, the right to liberty and security, respect for private and family life, freedom of thought, conscience and religion, freedom of expression and information, freedom of assembly and association, right to property, protection in the event of removal, expulsion or extradition, and the presumption of innocence and right of defence, had the same meaning and scope as the corresponding Articles of the ECHR. It should nonetheless be recognised that there are a number of Charter articles where the relationship with the ECHR rights is more complex, ${ }^{5}$ albeit for different reasons. Some Charter rights, such Article 5 dealing with slavery and forced labour, are based on an ECHR right in part, but go beyond it, by expressly prohibiting trafficking in human beings. Other rights, such as Article 8 dealing with personal data, are based on more than one source, in this instance an EC Treaty article plus directive, as well as an ECHR right. Yet other Charter rights modify the analogous ECHR right. This is exemplified by Article 9 of the Charter, which countenances the possibility of marriage by those of the same sex, where this is permitted by the relevant national law. There are also instances where the Charter article is based on more than one source, and modifies the relevant ECHR right. This is so for the right to education, and for the important right to equality. The other major injunction in Article 52(3) is that the meaning and scope of Charter rights that correspond to ECHR rights should be the same as those laid down in the ECHR. This may be problematic, where the $\mathrm{ECHR}$ jurisprudence on the point is unclear, or where the point is a novel one.

In conceptual terms, the fit between Article I-7(2) and I-7(3) of the Constitution is also problematic. The latter stipulates that the fundamental rights contained in the ECHR shall constitute general principles of Union law. This conceptualisation of the status of ECHR rights may be acceptable pending accession by the Union to the ECHR. The status and meaning of Article I-7(3) if and when the Union accedes is more problematic. It is clear from the perspective of public international law that if the Union accedes to the ECHR then it is bound by its treaty obligations. It may be that the intent is to create something equivalent to the HRA position, whereby the ECHR case law is persuasive but not binding on the Community courts even after the Union's accession. This does not however follow from the wording of Article 1-7(3) as it is presently drafted.

\section{(d) The Community Courts}

The discussion of the Community courts by the Convention on the Future of Europe can scarcely be regarded as satisfactory, either in terms of process or outcome.

In terms of process, there was no working group established to consider the implications of the draft Constitution for the role of the Community courts. A discussion circle was convened late in the day to consider certain aspects of the Community judicial system. The time for discussion was however severely limited, and similar limits applied in relation to the topics that were placed on the agenda. The provisions in the draft Constitution largely repeat those to be found in the Nice Treaty, because there was no time to consider more far-reaching changes that might have been beneficial. Thus the possibility of moving beyond the Nice Treaty to a rational Community judicial system in which the $\mathrm{CFI}$, now to be known as the High Court, becomes a general first instance court for all types of disputes, direct actions and preliminary rulings irrespective of who brings the action, was never discussed. Nor was there any consideration given to the key issue of whether we retain a referral system, or move towards a more appellate regime. These are matters of general principle that should have been discussed within a body drafting a Constitution for Europe, and this is so whatsoever one might think the answers should be.

In terms of outcome, the conclusions reached by the Discussion Circle and embodied in the draft Constitution on some of the topics that were considered are contentious. The possible modification of Article 230 was one of the issues considered by the Discussion Circle, which was split on the matter. ${ }^{6}$ One group felt that the current formulation was in fact satisfactory and provided effective judicial protection, taking account of the options for indirect challenge under Article 234. They felt that it was not necessary to make any substantive changes to Article 230(4). Another group felt that the current wording of Article 230(4) was too restrictive and a number of proposals were put forward to broaden standing for non-privileged applicants. Given the division of opinion, the Chairman of the Circle, Antonio Vitorino, proposed a compromise wording of Article 230(4), which has been taken up in to the draft Constitution in Article III-266(4), ex 230(4): "Any natural or legal person may, under the same conditions, institute proceedings against an act addressed to that person or which is of direct and individual concern to him, and against a regulatory act which is of direct concern to him without entailing implementing measures". This left the basic approach in Article 230(4) unchanged, save for situations where a regulatory act could affect the individual without the need for implementing measures. In such circumstances there would then be standing provided that the applicant could show direct concern. The other provision which is of relevance in this regard is Article I-28(1), the second sentence of which stipulates that the Member States shall provide rights of appeal sufficient to ensure effective legal protection in the field of Union law. From the perspective of the individual, these reforms do not touch the deeper problems with the restrictive rules of standing for direct actions addressed by Advocate General Jacobs in the UPA case. These problems are exacerbated by the decision to make the Charter binding: a regime of Community enshrined rights requires an adequate system of remedies. It will be scant comfort to those who seek to enforce Charter rights against Union acts to be told that even though they possess such substantive rights, they do not have an interest sufficient to allow them to challenge the norm directly, but will have to fight their way through at least one national court before getting close to the ECJ. It is in this sense 'constitutionally asymmetrical' to include a provision in Part One of the Constitution, Article 1-28, which exhorts the Member States to provide sufficient legal protection in the field of Union law, while saying nothing about any similar obligation on the Union concerning access to justice. The retention of the limits on direct challenge is, somewhat paradoxically, equally problematic from the perspective of the Community courts. The problems of workload have been especially acute in relation to preliminary rulings. By retaining the limits on direct challenge, and by forcing claimants through indirect challenge, the ECJ is forced to hear challenges to the validity of Community norms that should and could be heard by the CFI, which would thereby alleviate the ECJ's work-load. 


\section{The Vertical Perspective: The Relationship between Member States and the EU}

\section{(a) Competence: Clarity, Containment and Consideration}

\section{The Nature of the 'Competence Problem'}

It is clear that the issue of competence is central to the relationship between the EU and the Member States in the new constitutional order. This was indeed one of the key issues specifically singled out for further investigation after the Nice Treaty in 2000.

It is important at the outset to understand the 'causes of the competence problem'. The EU has always had attributed competence: it can only operate within the powers granted to it by the Member States. The EU's power can be expanded by a broad interpretation accorded to existing Treaty provisions, either legislatively or judicially, by a teleological view of Article 308 (ex 235), or by the attribution of new competences to the EU through successive amendments to the Treaties. There is no doubt that the existing range of EU competence is a result of all three developments. There are nonetheless differences of view as to the relative importance of these factors. For some the sphere of EU competence has been expanded primarily through the broad interpretation accorded to Treaty articles, both legislatively and judicially, and through the broad interpretation of Article 308. Others acknowledge the impact of the ECJ's jurisprudence, but place equal emphasis on the conscious decision by the Member States to grant the EU competence in areas such as the environment, culture, health, consumer protection, employment, and vocational training. I fall into this latter camp. The idea that the 'competence problem' is for example solely or principally the result of judicial decision-making ignores the fact that very important expansion in the areas over which the EU has competence has been the result of a conscious decision by the Member States. These decisions were reached after extensive discussion within Inter-Governmental Conferences. The fact that the EU wields a degree of competence in such areas can scarcely be regarded as illegitimate given that the Member States consciously consented to this grant of power. It is therefore mistaken to think about competence within the EU by means of a direct analogy with the distribution of power in other federal polities, where the divide is based on some general constitutional provision, such as an inter-state commerce clause, with the courts having the principal responsibility for determining the ramifications of this clause for federal/state relations.

It is equally important to understand that any view concerning the provisions on competences found in the new Draft Constitution will necessarily be affected by perceptions as to what was, and should be, the primary aim of the constitutional provisions in this area. We cannot judge the success or failure of the enterprise without some understanding as to the objects being sought. In general terms, there were three principal forces driving this part of the reform process: clarity, containment and consideration. The desire for clarity reflected the sense that the Treaty provisions on competences were unclear, jumbled and unprincipled. The desire for containment reflected the concern, voiced by the German Lander as well as some Member States, that the EU had too much power, and that it should be substantively limited. This argument must nonetheless be kept in perspective. We have already seen that a significant factor in the present distribution of competence has been the conscious decision of the Member States to grant new spheres of competence to the EU. This is where the third factor comes into play, consideration of whether the EU should continue to have the powers that it has been given in the past, a re-thinking of the areas in which the EU should be able to act. The reality is that there has been little re-thinking of the areas in which the EU should be able to act. I say this not by way of criticism, but by way of explication for the subsequent discussion. The Convention did not conduct any root and branch re-consideration of the substantive heads of EU competence. Nor would this realistically have been possible within the time available. The strategy was, in general terms, to take the existing heads of competence as given. The emphasis was on clarity and containment.

The provisions on competence are contained in Title III of Part I of the Draft Constitution. ${ }^{7}$ Article I-9(1) stipulates that Union competences are based on conferral and that their exercise is governed by subsidiarity and proportionality. This is reinforced by Article 1-9(2), which provides that the Union must act within the limits of the competences conferred on it by the Member States, and that competences not conferred on the Union remain with the Member States. There then follow provisions on subsidiarity, proportionality and primacy that will be considered in detail below. The categories of competence are set out in Article $1-11$. It is clear that the divide between these categories has been the subject of intense debate within the Convention. The 'walls' between the categories have shifted significantly and continue to do so.

\section{Exclusive Competence}

The consequence of inclusion within the list of exclusive competence is clear. It is only the Union that can legislate and adopt legally binding acts in such areas, the Member States being able to do so only if so empowered by the Union or for the implementation of acts adopted by the Union, Article I-11 (1).

The domain of exclusive competence comes out reasonably in terms of clarity. The areas deemed to fall within exclusive competence are competition rules within the internal market, monetary policy for the Member States that have adopted the Euro, common commercial policy, customs union, and the conservation of marine biological resources under the common fisheries policy, Article 1-12(1). There may of course be borderline issues as to whether action falls within one of these areas, as opposed to the that of shared competence. Borderline disputes of this nature are inevitable whenever lines are drawn. The categories that comprise exclusive competence are however relatively discrete, and borderline disputes should not be too difficult to resolve.

The domain of exclusive competence also fares pretty well when judged by the desire for containment. The consequences of inclusion within this category are severe: the Member States have no autonomous legislative competence. A broad reading of exclusive competence would therefore have had the opposite effect of containment, since it would enhance the power of the centre at the expense of the Member States. The importance of this point is readily apparent by considering earlier formulations of this category. The main change from the earlier formulation is the removal of the four freedoms from the sphere of exclusive competence, and their re-assignment to the category of shared 
competence. The reason given for this change is that there is now a specific provision dealing directly with the four freedoms, Article $1-4$, which is said to make their legal and political importance more visible than hitherto, and to underline the fact that they are directly applicable. While it might be felt to be desirable to for political reasons to emphasise the centrality of the four freedoms, the argument based on direct applicability is odd to say the least, given that many other Treaty provisions have this quality. The real reason for the excision of the four freedoms from Article 1-12 may have been rather different. If they had remained within the category of exclusive competence, Member States would have had no legislative capacity in these areas. Taken literally, this would have meant that a Member State would have been precluded from enacting legislation that, for example, liberalised trade in postal services, unless it had first secured the agreement of the Union. Thus, Member State action which was 'ahead' of EU action would have been precluded even though it may have been in accord with the overall aims of the EU, and even though it may well have been the catalyst for EU action in such areas. ${ }^{8}$

\section{Shared Competence}

The basic provision on shared competence is found in Article I11(2). When a competence is shared then the EU and the Member States have power to legislate and adopt legally binding acts within that area. However the Article also provides that the Member States shall exercise their competence to the extent that the Union has not exercised or has decided to cease exercising its competence. The provisions in this area can be assessed in terms of the twin aims of clarity and containment.

Let us consider clarity first. It is now clear that shared competence is the default position. This is readily apparent from Article 1-13(1), which provides that where the Constitution confers a competence that is neither exclusive nor supporting it shall be regarded as being a shared competence. The detailed list of areas set out in Article 1-13(4), are then merely examples of the principal areas where shared competence operates. This does provide some degree of clarity, albeit to a limited degree. It should nonetheless be recognised that the way in which power is shared in the diverse areas covered by the general category of shared power differs significantly. The precise configuration of power sharing in areas such as the internal market, consumer protection, energy, social policy, the environment, and the like can only be determined by considering the detailed rules that govern these areas, which are found in Part III of the Constitution. There is nothing in the discussion of the Title on competences that will help the interested onlooker to work this out. There, is in other words, subject to what will be said below, no magic formula that applies to all areas of shared power that determines the precise delineation of power in any specific area. This is not a criticism as such. It is rather the consequence of the fact that the EU has been attributed competence in different areas through successive Treaty amendments, coupled with the fact that the precise degree of power it has been accorded will differ as between these areas. The direct consequence is that the regime of shared power, the amount of power wielded by the EU, and that left to the Member States, will be different in these diverse spheres. This is recognised in Article 1-11(6), which states that the scope and arrangements for exercising the Union's competences shall be determined by the provisions specific to each area in Part III of the Constitution.

Let us now consider containment, the other objective underlying the provisions on competence. Article I-9(1) and (2) provide the basic touchstone that the EU only has competence in the areas conferred on it, and that any other competence remains with the Member States. This foundational provision must however be seen in the light of the more detailed provisions that come thereafter. In the context of shared power, which is as we have seen the default position, the Member State can only exercise power in areas of shared competence to the extent that the Union has not exercised or has decided to cease to exercise its competence within these areas, Article l-11(2). Taken literally this looks like automatic pre-emption of Member State action where the Union has exercised its power. The consequence is that the amount of shared power held by the Member State in these areas would diminish over time. Power sharing would on this view be a one way bet, subject to the remote possibility that the EU decides not to exercise its competence within a specific area. If containment is the prime objective, then there is little here to give comfort to supporters of states' rights. This conclusion as to the import of Article 1-11(2) is however misleading in two respects. Member States will only lose their competence within the regime of shared power to the extent that the Union has exercised its competence. Precisely what the EU's competence actually is within these areas can only be divined by considering the detailed provisions that divide power in areas as diverse as social policy, energy, the internal market and consumer protection. Moreover, it would be wrong to conclude that the Member States lose their competence even where the EU has exercised its competence, notwithstanding the wording of Article I-11 (2). EU legislation may entail complete harmonization, but it may also be framed so as to constitute minimum harmonization, with the specific intent of leaving Member States with room for action in the relevant area. There is nothing in the new Constitution to suggest that this latter option should not be open. To the contrary, the thrust of many of the constitutional provisions is to ensure that the EU does not legislate where action is better taken at national level. The upshot is that the real limits on Union competence must be found in the detailed provisions in Part III which delineate just what the EU can do in the diverse areas where power is shared. It is these provisions, and the way in which the EU decides to legislate within these areas, that will determine the reality of the divide between state power and EU power. This is of course what we have always had to do in order to determine the boundaries between state and EU power.

\section{Areas of Supporting, Co-ordinating or Complementary Action}

The third principal category of competence is set out in Article I$11(5)$. This stipulates that in certain areas and in the conditions laid down in the Constitution, the Union shall have the competence to carry out actions to support, support or coordinate the actions of the Member States, without thereby superseding their competence in these areas. Article I-16 specifies the areas where the EU has this type of power. They are: industry; protection and improvement of health; education, vocational training, youth and sport; culture; and civil protection.

There can be little doubt that judged in terms of clarity this category of competence will prove to be problematic. The list 
of areas in Article I-16 may well be clear, but the problem resides in the potential for overlap and boundary problems between this category and that of shared power. This is acknowledged in the Praesidium's comment, where it is accepted that regulation of the media may come under the internal market, which is shared power, and culture. ${ }^{9}$ Certain aspects of public health come within shared power, others within the category of supporting action.

This category of EU competence is also problematic when viewed from the perspective of containment. This comes to the fore in the tension between Article 1-11(5) and Article 1-16(4). The former is framed in terms of EU action not 'superseding' Member State competence in these areas. The latter provides that legally binding acts of the Union adopted on the basis of the provisions specific to these areas cannot entail harmonization of Member States' laws. While it is clear that the EU cannot harmonize the law in these areas, it is equally clear that it can pass legally binding acts, the scope of which will, in accord with Article $1-11(6)$, be determined by the provisions specific to each of these areas. Where the EU does enact such legally binding acts they will bind the Member States. The competence of the Member States will be superseded within the area covered by the legally binding act, although the latter may of course allow the states some choice/discretion, depending on the type of law enacted.

\section{The Co-ordination of Economic, Employment and Social Policy}

The categories of competence discussed thus far have a certain symmetry. A division between exclusive, shared and supporting competence can be understood, notwithstanding the difficulties mentioned above. The existence of a specific head of competence dealing with common foreign and security policy is also readily explicable, given the distinct rules that apply in this area. The creation of a particular head of competence in Article $1-11$ (3) to deal with economic and employment policy is more problematic. Article I-14 spells out this category of EU power in greater detail. Article $1-14(1)$ states that the Union shall adopt measures to ensure the co-ordination of the economic policies of the Member States, in particular by adopting broad guidelines for these policies. The Member States must coordinate their economic policies within the Union. Article I-14(2) provides that specific provisions shall apply to those member States that have adopted the Euro. Employment policy is dealt with in Article 1-14(3), which states that the Union shall adopt measures to ensure the co-ordination of Member State employment policies, in particular by adopting guidelines for these policies. It is further provided in Article 1-14(4) that the Union may adopt initiatives to ensure co-ordination of Member State social policies.

The very existence of this category has proven to be controversial, with some members of the Convention calling for these areas to come within shared competence, while others argued for the inclusion of employment as well as economic policy within this separate category. The Praesidium felt that this should be retained as a distinct category because the specific nature of co-ordination of economic and employment policy merited separate treatment. ${ }^{10}$ This somewhat Delphic utterance provides little by way of reasoned explanation. The real explanation as to why it was felt desirable to single out these areas for separate treatment within the regime of Union competence was political. There would have been significant opposition to their inclusion within the head of shared competence. The very depiction of economic policy as an area of shared competence with the consequence of pre-emption of state action would have been potentially explosive in some quarters at least. It is equally clear that there were those who felt that the category of supporting, co-ordinating and complementary action was too weak. Hence the creation of the separate category, and hence its placing after shared power, but before the category of supporting, co-ordinating and complementary action.

This may well have been the rationale for the creation of this category, but it does little to enhance the sense of clarity in the regime of competences overall. This is in part because, by way of contrast to the other heads of competence, Article I-11 does not specify any general consequences for the divide between state power and EU power for this category. It is in part because of the overlap between Article I-14 and the category of shared power dealt with in Article 1-13. Thus, for example, certain aspects of social policy are regarded as coming within shared power, while others fall within the category dealing with economic, employment and social policy.

\section{(b) The Primacy of EU law}

The primacy of EU law over national law has not hitherto been enshrined as part of the Treaties. The supremacy doctrine has, as is well known, been developed by the ECJ, and has met with a mixed reception from Member States' courts. The draft Constitution has now bitten this particular constitutional bullet: Article 1-10(1) provides that the Constitution and law adopted by the Union's institutions in exercising competences conferred on it, shall have primacy over the law of the Member States. This is reinforced by Article 1-10(2), which stipulates that Member States shall take all appropriate measures, general or particular, to ensure fulfilment of the obligations flowing from the Constitution or resulting from the Union Institutions' acts. So does this signal the death of one of the staple topics in EU law courses? Does it close the chapter on this part of EU scholarship? Not quite, for the following reasons.

Firstly, the phrase "shall have primacy over the law of the Member States" is ambiguous. This could be interpreted to mean, following the jurisprudence of the ECJ, that supremacy operates over all national law, including provisions in a national constitution. It could alternatively be read so as to accord primacy to EU law over national law, primary and secondary legislation, but not the national constitution itself.

Secondly, it remains to be seen whether the constitutional courts of the Member States will regard such a provision as acceptable from the perspectives of their own national constitutions. The idea that a Union regulatory act, in effect secondary legislation, should be deemed to have primacy over the law of the Member States might not be readily accepted by some constitutional courts, more especially so if this is taken to include primacy over national constitutional norms as well as national legislation. They might rule that their national constitutions do not allow ratification of a Constitution in such terms. 
Thirdly, insofar as Article 1-10(1) confers supremacy on Union law the conceptual foundation will almost certainly be treated by Member State courts as continuing to flow from their own constitutional provisions rather than the more communautaire reasoning of the ECJ. Supremacy of Union law will be held to exist because the Member States have agreed to this by their ratification of the Constitution. It will not necessarily be treated as inherent in the Community order.

Fourthly, Article I-10(1) only accords primacy to Union law "in exercising competences conferred on it". There is nothing within this wording that resolves in and of itself, the issue of Kompetenz-Kompetenz: who is to decide on the ultimate boundary of Union competences, the ECJ or the Member State courts. Nor is there anything in Article I-28 that resolves this issue. The wording of Article 1-9, which emphasises the principle of conferral/attribution, does nothing to bolster the claims of the Union to decide on the ultimate boundaries of competence. The issue as to the boundaries of Union competence can arise, as we have seen in Brunner, either as a result of judicial action or as a result of legislative action. Thus an individual might argue before a national court that action is beyond the EU's competence because the ECJ has accorded an interpretation to certain articles of the Constitution that they cannot properly bear. An individual might in a similar vein contend that the Union legislature has enacted acts that go beyond those that could be based on the particular article in question. The very fact that Union competences have been divided in the manner considered above renders this type of challenge more likely than before. This is especially so in relation to the divide between shared competence, and competence that only allows supporting and co-ordinating action by the Union, or in relation to the divide between shared competence and the competence over economic and employment policy. We have already seen that the boundary lines between these heads of competence can be difficult to discern in relation to certain types of subject matter. It is also open to question whether Charter rights should be regarded in conceptual terms as conditioning the exercise of Union competence. The argument in favour of this interpretation is that the Charter is binding, with the consequence that Union acts, even if prima facie made in relation to an area over which the Union has conferred competence, will not be valid if they violate Charter rights.

Fifthly, there is a nice point as to whether subsidiarity and proportionality serve to define the boundaries of Union competence. We should recall here that Article 1-10(1) accords primacy to Union law in "exercising competences conferred on it". There is clearly a distinction between the limits of competence, and the use of competence that has prima facie been accorded to the Union. This dichotomy comes over in Article I-9(1), which stipulates that subsidiarity and proportionality are to govern the use of Union competence. Article 1-10(1) clearly serves to condition the primacy of Union law by insisting that it be made within the limits assigned to the Union, such that law can only be made within one of the designated areas, energy, consumer protection and the like. The issue is whether the word exercising within Article 1-10(1) also conditions the primacy of Union law in relation to the way in which conferred powers are used, with the consequence that if subsidiarity and proportionality are not complied with the resulting Union law does not have primacy over Member State law.
Finally, a word should be said more specifically about the effect of Article I-10 from the perspective of UK constitutional law. The answer in brief is as follows. A Union Constitution, duly ratified by an Act of Parliament, which includes this Article would be accepted by the courts. They would almost certainly reason as they have done in the past, that the Act of Parliament ratifying the Constitution should be regarded as an exercise of sovereignty by the existing Parliament. The key issue would then be the effect of later UK legislation, which was inconsistent with a Union act. The UK courts have already acknowledged that the doctrine of implied repeal, whereby an inconsistency between an earlier and a later norm is resolved in favour of the latter, will not apply in relation to a clash between Union law and domestic law. The existence of Article 1-10(1) would reinforce this position. The courts would therefore construe UK legislation so as to be compatible with Union law, and hence compatible with Article I-10(1). The problematic case would arise if Parliament stated expressly and unequivocally that it was derogating from a specific Union act, while remaining in the Union. The courts would then be faced with a choice. They could say that in such circumstances the latest will of Parliament has to take priority, even if this entails a breach of Union law. They could alternatively say that in the light of inter alia Article I$10(1)$ it is not open to a UK Parliament to derogate from a particular Union act while remaining within the Union.

\section{(c) The Charter of Rights}

It is clear that the Charter of Rights has implications for the Member States as well as the EU. Article II-51(1) defines the scope of application of the Charter. It is addressed to the institutions, bodies and agencies of the Union with due regard to the principle of subsidiarity, and to Member States only when they are implementing Union law.

In substantive terms, while there has been debate about the precise meaning of the word 'implementing' the ECJ will in all probability decide that this covers the same sphere of state action as its previous jurisprudence under the fundamental rights doctrine. This covers cases such as Wachauf, where the Member State acts as agent for the implementation of a Community norm. It covers also cases such as ERT, where the ability of the Member State to use the exceptions to, for example the rules on free movement, is judged for compliance with EU fundamental rights. The binding nature of the Charter on Member State action would also operate when Member States are implementing a framework law, or what used to be known as a directive. It should also be recognised that in the cases that do fall within the sphere of implementation, the national courts will have to adjudicate on a much broader range of rights than those currently found in the HRA. The legality of Member State action in such cases may be tested for compliance with some social and economic rights, as well as the more traditional civil and political rights.

In procedural or jurisdictional terms, adjudication on rightsbased claims against the state will become more complex. This is in part because claimants will be able to get at ECHR rights either through the HRA or, in cases where there is implementation of Union law, through the Charter rights included in the Constitution. There may moreover be incentives to use the latter route, since Convention rights mediated through Union law may provide a 
more potent weapon than the HRA. This is particularly so where the incompatibility with ECHR rights flows from primary legislation. In such instances the courts are limited to making a declaration of incompatibility under section 4 of the HRA. However, the supremacy law of Union law applies in relation primary legislation itself. The Member States' breach of Union law may consist of failure to comply with the Community Charter of Rights. The national courts could then declare that the primary legislation was actually inapplicable to the instant case, rather than simply making a declaration of incompatibility under section 4 of the HRA. The procedural or jurisdictional complexity may also arise because of the different force accorded to ECHR rights under the HRA and the Charter. Under the HRA national courts have an obligation to take account of the Strasbourg case law. They are not bound to follow it. The national courts are bound to apply Union law, and the EU has committed itself to giving the same interpretation to those Charter rights that are also in the ECHR.

Article II-53 is also of direct relevance for Member States. It is entitled 'Level of Protection'. It provides that nothing in the Charter is to be interpreted as restricting or adversely affecting human rights recognised, in their respective fields of application, by Union law and international law and by international agreements to which the Union, the Community or all the Member States are party, including the ECHR, and by the Member States' constitutions. The aim of this provision was said to be to maintain the level of protection 'currently afforded within their respective scope by Union law, national law and international law'. ${ }^{11}$ There are two difficulties in relation to Article II-53 as it applies to Member States.

There is, on the one hand, an ambiguity as to the import of the phrase 'in their respective spheres of application'. It appears to mean that nothing in the Charter should be interpreted as restricting etc human rights recognised in the respective areas to which public international law, international agreements and Member State constitutions apply. It therefore delineates the spheres of application of human rights norms derived from these other areas. This is problematic in relation to human rights recognised in Member State constitutions. The jurisprudence from German and Italian courts is not premised on the assumption that their human rights norms only apply within a limited field, being that to which Community rules do not apply. It is premised rather on the assumption that such national constitutional protection continues to be generally applicable, but that national courts might choose not to exercise their jurisdiction if satisfied that the protection of rights within the Community legal order is (generally) sufficient.

There is, on the other hand, the problem that Article II-53 is framed in terms of Member States' constitutions, in the plural. It is clear that the list of constitutional rights contained in national constitutions is not identical. It is equally clear that the particular conception or meaning accorded to the same right varies as between states. This creates an obvious difficulty for the ECJ faced with the application of Article II-53. The interpretation of a Charter right might adversely affect human rights as protected within the constitution of one Member State but not another. The difficulty would be exacerbated if it was a zero sum game, such that the interpretation of the Charter right to accord with one Member State constitution necessarily was adverse to the interpretation of the same right in other national constitutions. The injunction in Article II-52(4), that Charter rights that result from the constitutional traditions common to the Member States shall be interpreted in harmony with those traditions, might alleviate the problem, but will not necessarily resolve it.

It might be argued that this is a false problem, since the only national constitution that should ever be relevant is that of the state from which the facts of the case emanate. This will not withstand examination. The meaning given to the Charter right might originate in the context of a case concerning the validity of a generally applicable Community regulation, where the particular state that refers the matter is fortuitous. Moreover, the interpretation given to a Charter right in a case which occurs in, for example, Spain could have very real implications for other countries.

The difficulty could nonetheless be resolved in some cases by applying a margin of appreciation. Where Charter rights apply to Member State action in accord with Article II-51, it might be legitimate to tailor the interpretation of the right to that particular Member State through the margin of appreciation, thereby obviating any clash with that national constitution. In other cases, this will not however be possible. The construction of a Charter right might arise in a case concerning Member State implementation of EC law, where, as in ERT or Familiapress, another Member State's laws are directly implicated in the action. It is perfectly possible for an interpretation of the Charter right to affect adversely the constitutional right protected by one Member State, while the contrary construction would be regarded as constitutionally objectionable by the other state. In these circumstances the ECJ will necessarily have to make difficult choices. Working Group II of the Laeken Convention proposed an amendment to the Charter, to the effect that insofar as the Charter recognises fundamental rights as they result from the constitutional traditions of the Member States, the rights shall be interpreted in harmony with those traditions. ${ }^{12}$ This will not however in and of itself resolve the tensions considered above.

\section{NOTES}

* Professor of English Law, St. John's College, Oxford. This is the text of a lecture given at the British Institute of International and Comparative Law on Friday 13th June 2003

1 CONV 797/03, Brussels 10 June 2003.

2 CONV 770/03, Brussels 2 June 2003, p. 2.

3 This was reconfirmed by CONV 354/02, Final Report of Working Group II, 22 October 2002, p. 7.

4 Charte 4473/00, Convent 49, 11 October 2000, p. 49.

5 lbid., pp. 49-50.

6 Discussion Circle on the Court of Justice, CIRCLE I, Working Document 08, Brussels 11 March 2003.

7 CONV 724/03, Brussels 26 May 2003.

8 This conclusion could only be avoided by qualifying the peremptory wording of Article $1-11$ (1) so as to make it read something quite different. It would be necessary in effect to add a further clause at the end of the provision to the effect that Member States would be able to legislate where the legislation was in accord with the principles of free movement. This would fundamentally alter the whole nature of exclusive competence.

9 CONV 724/03, n. 7, p. 82.

10 lbid. p. 68

11 Charte 4473/00, Convent 49, 11 October 2000, p. 50

12 CONV 354/02, Final Report of Working Group II, 22 October 2002, pp. 7-8. 